\title{
Bureaucratic Structure Aspect in Implementation of Indonesian Finance Policy About Accrual Based Accounting in Local Government
}

\author{
Sri Suwitri Koesdali ${ }^{1}$, Hadiyati Munawaroh ${ }^{2}$, Warella ${ }^{3}$, Kismartini $^{4}$ \\ ${ }^{1.3 .4}$ Diponegoro University Semarang, Central Java, Indonesia \\ (sri_suwitri@yahoo.co.id, prof.y.warella@gmail.com, kismartini@yahoo.co.id ) \\ ${ }^{2}$ Supreme Audit Board of Indonesia in Province of Central Java (Branch Office) \\ (hadiyati.munawaroh@gmail.com)*
}

\begin{abstract}
Financial managementisan importantpartof thepublic administration. Implementation of Finance Policy of Indonesian Government about transparencyandaccountabilityin thefinancial managementsystemis connectedbythe financial report. Accrual-based financialreport has become ahallmarkof modernmanagement but its implementation is not easy. Transition from current accounting based to accrual based needs big changes and long terms project .The problems of accrual based implementation are more difficult in local government because of its characteristic of bureaucratic structure with SOPs and fragmentation.
\end{abstract}

Keywords: Accrual, Fragmentation, Implementation, SOP

\section{Introduction}

State financial management in Indonesia has undergone major changes since the release the legislation package on state finances, in Law Number 17 of 2003 Year on State Finance, Law Number 1 of 2004 Year on State Treasury and Law Number 15 of 2004 Year concerning Audit of State Finance and Accountability. The legislation package on the state finances becomes a strong legal foundation for implementing state financial management reforms. The Laws on state financial management has set out clearly and firmly on the financial and asset management system that follows the development of public sector management in order to promote the establishment of the transparent and professional state financial management.

Law Number 32 of 2004 Year on LocalGovernment gives autonomy to the regions included in the financial management area. Although the President has handed over the financial management to the Regional Head, but the arrangements of local's financial management has to be implemented within the framework of the state financial administration system.Although the President has handed over the financial management to the Regional Head, the arrangements of local's financial management has to be implemented within the framework of the state financial administration system. Regional Head must obey the laws and government regulations and ministerial regulations about state financial management, including local financial management.

Local financial management regulations are enermous and often changes. Before the Indonesian reformation era, local financial managements were simple with single entry acounting and incremental budgeting. The reformation which requires transparence and accountability in the state financial management promotes the implementation of modern financial managements. One of them is by implementing modern accounting.Government regulation concerning on Governmental Accounting Standard which has been released in 2005, enforce regional government to perform the changes on traditional financial management system which has been implemented before. The changes of financial management system requires the changes on local government bureuctation structure, that is Standard Operational Procedures and function fragmentation 
attached on organization structure. Before the local government had totally completed in following the changes, it must start to face the changes of government accounting standard on 2010. The change of Governmental Accounting Standard, which had been published on 2010, orders the implementation of full accrual basis accounting being performed at least in 2015 .

Implementation experience of accruals accounting in public sector in some countries shows the need of enermous resources as well as the need of long time, so the Government must performs a well preparation before implementing accruals accounting. Wynne (2004: 22-25) explains the Britain's experience in implementing accruals accounting:

"Accruals accounting is, however, complex and requires more resources both financial and people to operate and many of the necessary skills are still being developed in departments".

The IFAC's statement regarding French's accounting reformationwhich has started to implement accruals accountingin 2005(in Wynne 2004: 6):

"Transition to accrual accounting is a long-term project. National and international experience indicate that a time period of about 8 to 10 years is needed to change the accounting system and fully implement the necessary reforms".

IFAC (2003: 34) also express that:

"Transition is likely to be smoother and faster when the following features are present:

1) a clear mandate;

2) political commitment;

3) the commitment of central entities and key officials;

4) adequate resources (human and financial);

5) an effective project management and coordination structure;
6) adequate technological capacity and information systems; and

7) the use of legislation to provide formal authority and signal commitment to the changes".

With the background of changes of the financial management policy in local government, researcher see that it is important to perform a research to answer the qustion about: How bureaucracy structure aspect that is Standard Operating Procedures and fragmentation influence the implemention of financial policy on regional government?

\section{Methodology}

This study used a qualitative approach and case study method because the researcher intends to acquire indepth overview of the implementation of the financial policy of the Indonesian government in the district territority. This study is a single case study for examining the phenomenon in which the object of research is Semarang City Government as the only local governments that have implemented the governmental accounting standards based on accruals in arranging the financial statement. The implementation of accrual-based governmental accounting standards is the focus of this study because the standards are such new policies. Previously, local governments have been implementing cash-based accounting. Furthermore, previous studies concerning accruals-based accounting implementation in some countries founded that such implementation requires more changes than cash-based accounting did which have been implemented before. The changes are regarding Standard Operational Procedures, the competence of human resource, and the supply of technology-based financial information system. Big changes on accruals-based accounting implementation create 
some problems, sosome countries need long time to carry out.

Data collection techniques of the study are through interviews with the leader and executants of financial management in Semarang City Government anddocument analysis techniques. In addition, making observations was used, especially concerning financial statement preparation. Researcher also utilizes information from other parties such as academics who understand or pay attention to the government's financial statements, the Government Accounting Standards Committee (KSAP) which has developed the Governmental Accounting Standards (SAP) and auditors. This study had been performed from 2012 to 2013.

\section{Discussion}

Edwards III (1980: 11, 12 and 125) stated that organization structure in bureucration often being a hindrance in policy implementation when communication and human resources have been adequate.Two prominent characteristics of bureaucracies are standard operating procedures (SOPs) and fragmentation.

\subsection{SOPs Aspect in Accrual Accounting Implementation}

SOPs are routines that enable public officials to make numerous everyday decisions. SOPs save time, if a case worker had to invent a new rule for every potential client, few people would be helped and few problems would be solved. SOPs also bring uniformity to complex organizations and justice is better served if rules are applied uniformly. Uniformity by SOPs also makes personnel interchangeable. So detailed manuals are written to cover as many particular situations as officials can anticipate.
Financial management in regional governmentis regulated by many regulations not only central government regulations but also local government regulations. To implement these regulations, Semarang City Government arranges Standard Operating Procedures. When they started to implement accruals-based accounting, Semarang City Government was performing changes on SOPs to adapt accrual practice. The SOPs to implement the accruals-based accountingrefer to central government regulation.However, some central government regulations which are incomplete, unclear and inconsistent with other relevant regulations confuse Semarang City Government in developing the SOPs. Every change in the regulation requiresthe changes of SOPs, as well as the changes of cash-towards-accruals based to full-accruals-based rules.

The changes of SOPsrequires staffs to understand the SOPs. Furthermore, SOPscan be executed effectively if the staffs committee to change the routines in managing the finance to adapt the new SOPs. The staffs of Semarang City Government tend to be reluctant to change their routines in financial management with cash-based financial management which is simpler and easier become accruals-based which is less familiar and more complicated.

SOPs of accrual-based SAP also requirec omputerized-information system to support data processing which is sophisticated and complicated. While the staffs of Semarang City Government do not understand and are not familiar with the information technology in data processing. Them who are less understand accrual-based accounting and information technology will be bearing reluctance to perform new SOPs. 
Edwards III (1980) explained that a new policy tends to face problem in the implementation among others because of adequate human resources scarcity. The new policy also requires the will of personnel to change the routines. Moreover, the complicated policy should be supported with completed and comprehensive technical guidance. SOPs are most likely to hamper the implementation of new policies that require new modes of operation or types of personnel to implement them. Moreover, the more a policy requires change in the routines of an organization, the greater the probability of SOPs hindering implementation.

Accrual-based accounting policy is a new policy which is sophisticated and complex. Refer to Edwards III's theory, the implementation of accrualbased accounting will face a problem of human resources scarcity who understand the policy and a should be supported with completed and comprehensive technical guidance.However, in the implementation of accruals-based SAP, the technical guidance which should be created by central government, so it can be a guidance for the excecutor in regional government, even are still incomplete, unclear and inconsistent with relevant regionalfinancial management regulations. The technical guidance also often be changed. Moreover, implementation of accrual-based accounting needs changes in the routines of cash-based financial management in local government which is simpler and easier become accruals-based which is less familiar and more complicated. Refer to Edwards III's theory that the more a policy requires change in the routines of an organization, the greater the probability of SOPs hindering implementation, implementation of accrual-based accounting will face a problem. If staffs still remain following old standard routines that not needed at all in the accrual accounting may time consuming and wasteful.

\subsection{Fragmentation Aspect in Accrual Accounting Implementation}

The implementation of accrual-based accounting in the preparation of financial statement in Semarang City Government facesproblem of fragmentation in work area which has the correlation of job and function, while the coordination function between the units is not effective. The ineffective coordination occurs because of the lack of unit's authority who holds coordination function to perform coordination.The condition, at least, is found in the asset management and advertisement revenue management, as well as the internal audit function as quality control.Department of Asset, which is the third grade of authority, faces a problemwhen it performs the coordination with the other department'sleaders which are the second grade of authority (higher level). Besides, the Department of Assets must compile all asset data from all other departments. The internal auditor which is a member of budget arranger team which is headed by Regional Secretary, also find a hindrance in performing internal control function on the Regional Secretary's Department. The benefit whichcontains the weakness of quality control function by internal auditor as internal comptroller have been explained by Shafritz and Russel:

"Internal audit in organization can virtually serve as independent troubleshooters, providing early warning to top management of emerging problems. Internal auditors are always in danger of losing their independence to line management. Three key principles to be observed to ensure the degree of independence are: location outside line management, a hight reporting line for audit result, 
reasonable latitude in selecting assignments"

(Shafritz and Russel, 1997: 560-562).

Besides, advertisement revenue management is performed by four departments. The four departments do the difference function, that is financial recording, advertisement management, city arrangement, and advertisement permit. The problem of coordination in the advertisement revenue management occurs because of the unclearness of the department who holds the authority to perform coordination, also that each department has own policy which is unsynchronous and each of them tends to accentuate its own targets rather than the Semarang City Government's targets.

Refer to Edwards III (1980), the characteristic of bureaucratic organization, besides an SOPs, is the existence of fragmentation, that is the responsibility on a policy is divided into several organizations. The consequence of such fragmentation is the problem of coordination.A priority reason of an organization often interference the coordination with other organization.The priorities of agencies differ, and bureaucrats do not like to coordinate their actions with their counterparts in other agencies. The authority in coordinating the implementation often does not exist, or limited, or only in the paper. However, it is possible that the authority is adequate but the authority is ineffectively used. Moreover, with each agency having limited jurisdiction over an area, important tasks may fall between the cracks of organization structure. The wider the coordination needed to perform a policy, the smaller the possibility of the success of the policy implementation.

The lack of effective authority and fragmentation may be anticipated by performing cooperation or coordination with other executors. However, the implementation of accrual-based accounting in the preparation of financial statement in Semarang City Government faces problem with the coordination function between the units that is not effective. The problems of coordination not only cause important tasks are not executed but also cause the overlap and duplication that may time consuming and wasteful which hindering implementation of accrual based accounting.

\section{Conclusion}

Local government is bureaucratic organization which has bureaucracy structure characteristic that is SOPs and fragmentation. The local government financial management policy, which often changes, incomplete, unclear and inconsistent with other relevant regulations, complicate its implementation by local government. Local government's staffs are reluctant to change their routines according to the old SOPs, where as those are not relevant with accrual practice. Local government divide a function into several departments. To make the functions to be effective, it requires coordination among the departments. However, the coordination among the departments in performing such function is not effective, so it complicate the implementation of accrual-based local financial management policy.

\section{References}

(1) ABS, Australia. (2002). Implementation of Accrual Accounting in Australian Government Finance Statistics and The National Accounts. At OECD Meeting of National Account Expert, Paris.

(2) Blondal, John R. (2003). Accrual Accounting and Budgeting: Key Issues and Recent Development.OECD Journal on Budgeting, 3 (1) 
(3) Edwards, George C. (1980). Implementing Public Policy. Washington DC: Congresional Quarterly Press

(4) Gibson, Charles. (2007). Financial Reporting And Analysis (Using Financial Accounting Information), 10th edition. Canada: The University of Toledo,Emeritus

(5) Grindle, Merilee S. (1980). Politics and Policy Implementation in The Third World. New Jersey: Princeton University Press, Princeton

(6) Henry, Nicholas. (1975). Paradigms of Public Administration.Public Administration Review, 35 (No) 4 (Jul. - Aug)

(7) Hofstede, G. (1983). National Cultures in Four Dimensions. International Studies of Management and Organizations. 13, 46-74

(8) Hofstede, G and Bond, Michael Harris. No Year. The Confucius Connection: From Cultural Roots To Economic Growth.

(9) International Federation of Accountants (IFAC) Public Sector Commitee. (1994). Occational paper 1: Implementing Accrual Accounting in Government: The New Zealand Experience.

(10) International Federation of Accountants (IFAC) Public Sector Commitee. (2003). Transition to The Accrual Accounting: Guidance for Governments and Government Entities (Second Edition)/IFAC Study 14

(11) Khan, Abdul and Mayes, Stephen (IMF). 2007. Transition to Accrual Accounting. PFM Technical Guidance No. 1.
(12) K. Yin, Robert. (1987). Case Study Research: Design and Methods.

(13) Mazmanian and Sabatier. (1983). Implementation and Public Policy. Glenview: Scott, Foresman

(14) Najam, Adil. (1995). Learning from The Literature on Policy Implementation: A Syntetis Perspective.Laxenburg Austria: International Institute for Applied Systems Analysis

(15) Paudel, Narendra Raj. (2009). A Critical Account of Policy Implementation Theories: Status and Reconcideration. Nepalese Journal of Public Policy and Governance, XXV (2)

(16) Shafritz, Jay M and Russell, EW. (1997). Introducing Public Policy. New York: Longman

(17) Tudor, Tiron Adriana and Blidisel, Rodica. (2008). Accrual Accounting Experince in The Romanian Public Higher Education Sector. MPRA Paper No. 6690 Januari

(18) Wynne, Andy. (2004). Is The Move to Accrual Based Accounting a Real Priority for The Public Sector Accounting? London: The Association of Chartered Certified Accountants

(19) BPK's (Indonesian Supreme Audit Board).Audit Report about Financial Report of Semarang Government City Year 2010, 2011 and 2012

(20) Internal Auditor of Semarang Government. Internal Audit Report of City Year 2010, 2011 and 2012 